\title{
STRUČNO OSPOSOBLJAVANJE RADNIKA U SEKTORU ŠUMARSTVA - STANJE U HRVATSKOJ I TRENDOVI U EUROPI
}

\author{
VOCATIONAL TRAINING OF WORKERS IN THE FORESTRY \\ SECTOR - THE SITUATION IN CROATIA AND TRENDS \\ IN EUROPE
}

\author{
Matija LANDEKIĆ ${ }^{*}$, Ivan MARTINIĆ ${ }^{1}$, Matija BAKARIĆ ${ }^{1}$, Rosa M. RICART², Mario ŠPORČIĆ ${ }^{1}$
}

\begin{abstract}
Sažetak
U radu se razmatraju ključna pitanja osposobljavanja radnika za siguran rad u operativnom šumarstvu kao temeljnom uvjetu kvalitete i ekonomičnosti rada u šumarskoj proizvodnji. U osvrtu na stanje osposobljavanja u razvijenim europskih zemljama navode se obveze poslodavaca vezano za odgovarajuće osposobljavanje rukovatelja strojeva, uređaja i alata pri izvođenju šumskih radova. Pritom se prikazuju pristupi i trendovi u osposobljavanju u posljednjem desetljeću te modeli i postignuti dosezi s posebnim naglaskom na do sada razvijene sustave certificiranja osposobljavanja u Europi i ključne elemente takvih sustava. Kao primjer uspješnih rješenja prikazuju se modeli osposobljavanja putem šumarskih trening centara, gdje se obukom stečena znanja i vještine potvrđuju obveznom provjerom i izdavanjem certifikata. Stanje stručnog osposobljavanja šumskih radnika u Hrvatskoj razmatra se u kontekstu moguće primjene pojedinih europskih sustava certificiranja šumskog rada u Hrvatskoj. $S$ obzirom na potrebe, postojeće stanje osposobljavanja i profil ključnih aktera šumarskog sektora Hrvatske, kao najizglednijom za skoru primjenu u Hrvatskoj, ocjenjuje se provedba europskog standarda za rukovatelja motornom pilom. Zaključno se daje pregled zakonodavnih i organizacijskih zahtjeva za primjenu do sada razvijenih europskih modela u izgradnji sustava certifikacije osposobljavanja šumskih radnika u Hrvatskoj.
\end{abstract}

KLJUČNE RIJEČI: šumarstvo, šumski radnik, stručno osposobljavanje, obuka, certifikacija

\section{UVOD}

\section{INDRODUCTION}

U većini zemalja radovi u šumarstvu idu u red najopasnijih zanimanja s velikim ljudskim i financijskim gubitcima, pri čemu šumarska profesija spada u najopasnija zanimanja u području proizvodnje (ILO 1981, Bentley i dr. 2005, Potočnik i dr. 2009, Lindroos i Burström 2010, Marenče i Krč
2016). Stopa ozljeda u šumarstvu znatno je viša nego u drugim sektorima, što ujedno ovu struku svrstava u kategoriju sektora visokog rizika. Tako je zabilježena stopa ozljeda sa smrtnim ishodom u šumarstvu $S A D-a 19$ puta veća nego u drugim sektorima (Lefort i dr. 2003, Bell 2002). U australskom šumarstvu zabilježena je 2 do 3 puta veća stopa ozljeda u odnosu na ostatak industrije (Driscoll i dr.1995). U Njemačkoj je zabilježena tri puta veća stopa ozljeda sa smrt-

\footnotetext{
${ }^{1}$ dr. sc. Matija Landekić, prof. dr. sc. Ivan Martinić, izv. prof. dr. sc. Mario Šporčić, Matija Bakarić mag. ing silv., Sveučilište u Zagrebu, Šumarski fakultet, Zavod za šumarske tehnike i tehnologije, Svetošimunska 25,10000 Zagreb, e-mail: mlandekic@sumfak.hr, martinic@sumfak.hr, sporcic@sumfak.hr, mbakaric@sumfak.hr ${ }^{2}$ Rosa M. Ricart MSc in Occupational Risk Prevention, Centre Tecnològic Forestal de Catalunya (CTFC), Ctra. de St. Llorenç de Morunys km 2, 25280 Solsona, Spain, e-mail: rosa.ricart@ctfc.es

*autor za korespondenciju - corresponding author
} 
nim ishodom u odnosu na građevinarstvo i dva puta veća u odnosu na poljoprivredu, a u Španjolskoj je ostalim djelatnostima utvrđena 3 do 4 puta manja stopa ozljeđivanja nego u sektoru šumarstva (Cabeças 2007). Detaljnija analiza nesreća u sektoru šumarstva pokazala je da su radovi na sječi i izradi drva daleko opasniji od drugih šumskih radova (ILO 1991). Navedeno potvrđuje evidencija ozljeđivanja podatkom da je 65-80 \% svih nesreća u sektoru šumarstva, vezano uz aktivnosti kod sječe i izrade drva (Efthymiou 2008). Kod ručno-strojne sječe i izrade drva motornom pilom rušenje stabla te trupljenje debla i ostalih segmenata stabla prepoznato je kao aktivnost kod kojih se sjekač najčešće ozljeđuje (ILO 2012). Navedeni pokazatelji razine sigurnosti između šumarskog i drugih sektora poprimaju još veći numerički nesrazmjer kada dio radne snage nije adekvatno osposobljen (Klun and Medved 2007) za radove u šumarstvu.

Uvažavajući navedeno, na rizik od nastanka ozljede ne utječe samo razina mehaniziranosti radova u šumarstvu i izloženost radnika spram opisa radnog mjesta, već i stručna osposobljenost radne snage čija razina značajno utječe na rizik od ozljeđivanja. Profesionalni šumski radnici zaposleni na neodređeno vrijeme u šumskom poduzeću daleko se manje ozljeđuju od poljoprivrednika, samozaposlenih radnika i radnika sjekača zaposlenih kod privatnih izvoditelja. U Austriji, poljoprivrednici koji sezonski izvode radove pridobivanja drva bilježe dvostruko više nesreća na milijun $\mathrm{m}^{3}$ posječenog drva u odnosu na profesionalne radnike (Sozialversicherung der Bauern 1990), a u Švedskoj čak četiri puta više. U Švicarskoj radnici zaposleni u državnim šumama bilježe upola manje nesreća u odnosu na radnike zaposlene kod privatnih izvođača, posebice tamo gdje su radnici zaposleni samo sezonski i čine migracijsku radnu snagu (Wettmann 1992).

Obučavanje i periodično provjeravanje osposobljenosti radnika za rad s radnim sredstvom, te sukladno primjerenom radnom tehnikom, već se desetljećima drže ključem kvalitete rada i sigurnosti operativnoga rada u djelokrugu šumarstva i urbanog šumarstva. Navedeno pokrepljuju Häggström i dr. (2016) istraživanjem izloženosti rukovatelja šumske mehanizacije vibracijama te zaključkom da na izloženost vibracijama, a samim time i na veću razinu sigurnosti, znatno može utjecat stručna osposobljenost operatera te radna tehnika. U većini europskih zemalja propisi obvezuju poslodavce da osiguraju odgovarajuće osposobljavanje svakoj osobi koja uporabljuje radne alate i strojeve (Medved 1998). Isto tako obukom stečena znanja, tehnika rada i vještine potvrđuju se obveznom provjerom i izdavanjem certifikata kao dokaza o posjedovanju određenih profesionalnih znanja i vještina za siguran šumski rad (Martinić i dr. 2011).

U okviru provedenog istraživanja o profesijama i osposobljavaju u šumarstvu Europe i sjeverne Amerike, Bernas- coni i Schroff (2011) ističu da se obrazovni sustav širom svijeta nalazi u tranziciji. Isti autori navode kako je obrazovanje jedan od ključnih nama dostupnih resursa pomoću kojega struka može odgovoriti budućim izazovima. Navedeno se odnosi na obrazovanje u cjelini, te ciljano na osposobljavanje i obuku u šumarstvu, čime se jamči održivi razvoj šuma i struke. Također, u okviru objavljenih rezultata Bernasconi i Schroff (2011) navode da programi obuke i osposobljavanja u šumarstvu prolaze temeljnu reviziju i ažuriranje na teritorijalnoj razini i na razini stručnog osposobljavanja. Složenost i specijalizacija radnih zadatka šumskih radnika rezultirala je općim trendom sve veće ekspanzije očekivanih vještina i, sukladno tomu, programima izobrazbe u sektoru šumarstva.

Uvažavajući navedeno, fokus rada obuhvaća prikaz internacionalnih trendova i promjena u sustavu osposobljavanja i obuke u šumarstvu, s naglaskom na europsku praksu certificiranja šumskog radnika sjekača. Dodanu vrijednost rada čini prikaz stanja stručnog osposobljavanja šumskih radnika u Republici Hrvatskoj s legislativnim i tehničko-organizacijskim smjernicama za potencijalnu implementaciju EU modela certifikacije šumskih radnika u šumarstvu RH.

\section{MATERIJALI I METODE RADA MATERIAL AND METHODS}

Radi spoznavanja literaturne dimenzije predmeta istraživanja, izvršeno je pretraživanje relevantnih domaćih $\mathrm{i}$ inozemnih znanstvenih i stručnih izvora: Current Contents, Science Direct, ForestScience.info, Cab Abstracts i dr. te web stranica institucija (fakulteta, istraživačkih centara, centara za osposobljavanje, strukovnih udruženja i sl.) koje se bave problematikom stručnog osposobljavanja u sektoru šumarstva. Izvor koji je u značajnijoj mjeri korišten kao podloga za izradu rada je dokument pod naslovom »Zanimanja i osposobljavanje u šumarstvu - rezultati istraživanja u Europi i sjevernoj Americi«, koji je plod istraživačkog rada Bernasconia i Schroffa (2011). Drugi korišteni relevantan izvor koji daje detaljniji uvid u šumarsko obrazovanje, osposobljavanje i usavršavanje je Eduforest International internet platforma. Treći ključno važan izvor čini internet platforma Vijeća za europsko šumarstvo i okolišne vještine (European Forestry and Environmental Skills Council EFESC) koje se bavi upravljanjem i nadzorom vještina te procesom certifikacije kompetencija koje su vezane za aktivnosti radnog kadra u šumarstvu i prirodnom okolišu na nacionalnoj razini.

U tom kontekstu smatra se korisnim domaćoj znanstvenoj i stručnoj javnosti pružiti aktualna saznanja i informacije o (a) stanju stručnog osposobljavanja šumskih radnika u Hrvatskoj i (b) trendovima europskog modela certificiranja šumskog rada. 
Tablica 1. Mreže i programi u domeni osposobljavanja u šumarstvu na području Europe (Bernasconi i Schroff, 2011)

Table 1 Networks and programs in the field of training in forestry within Europe (Bernasconi i Schroff, 2011)

\begin{tabular}{|c|c|}
\hline $\begin{array}{l}\text { Mreže / Institucije } \\
\text { Networks/Institutions }\end{array}$ & $\begin{array}{l}\text { Opis } \\
\text { Description }\end{array}$ \\
\hline Eduforest International & $\begin{array}{l}\text { Eduforest predstavlja internet platformu koja ima za cilj promicati šumarsko obrazovanje, } \\
\text { osposobljavanje i usavršavanje u Europi, te lakše umrežavanje aktera istih interesa. } \\
\text { Eduforest is an internet platform which aims to promote forestry education, training and further } \\
\text { training in Europe and to facilitate the networking of actors. }\end{array}$ \\
\hline $\begin{array}{l}\text { Europski šumarski institut } \\
\text { The European Forest Institute (EFI) }\end{array}$ & $\begin{array}{l}\text { EFI je vodeća javna šumarska istraživačka institucija u Europi. } \\
\text { The EFI is the leading forestry research network in Europe. }\end{array}$ \\
\hline $\begin{array}{l}\text { Savez europskih šumara } \\
\text { Union of European Foresters (UEF) }\end{array}$ & $\begin{array}{l}\text { UEF je mreža privatnih i javnih šumskih organizacija koja također pruža pregled tečajeva treće } \\
\text { razine osposobljavanja. } \\
\text { The UEF is a network of private and public forestry organisations; the network also provides } \\
\text { overviews of third-level training courses. }\end{array}$ \\
\hline ENQuaFor & $\begin{array}{l}\text { ENQuaFor je Europska mreža za kvalifikacije u šumarstvu. } \\
\text { ENQuaFor is the European Network for Qualification in Forestry. }\end{array}$ \\
\hline $\begin{array}{l}\text { Europska mreža šumarskih poduzetnika* } \\
\text { European Network of Forest Entrepreneurs (ENFE)* }\end{array}$ & $\begin{array}{l}\text { ENFE pokreće i provodi razne programe koji se bave pitanjem vezanim za obrazovanje i osposo- } \\
\text { bljavanje poduzetnika u šumarstvu. } \\
\text { The ENFE runs various programmes dealing with the issues surrounding forestry education and training }\end{array}$ \\
\hline
\end{tabular}

* ENFE kao samostalna organizacija nestaje tj. ista djeluje u sklopu novoosnovane Europske organizacije izvođača u poljoprivredi, ruralnim područjima i šumarstvu (Ceettar)!

* ENFE as an independent organization disappears, i.e. the same acts within the newly established European Organisation of Agricultural, Rural and Forestry Contractors (Ceettar)!

U radu su korištene metode analize i sinteze, komparacije i kompilacije. Metode analize i sinteze korištene su u postupku izrade rada, gdje su razni izvori u konačnici sažeti $\mathrm{u}$ jedinstven tekst. Metoda komparacije primijenjena je u praktičnom djelu rada kod prikaza broja obrazovnih institucija spram vrste osposobljavanja koje pružaju, te kod prikaza stanja implementacije europskog standarda za motornu pilu na razini država članice EFESC-a. Baza za unos prikupljenih podataka, sistematizaciju i provjeru točnosti unosa te primarnu obradu prikupljenih podataka izrađena je u programskom paketu Microsoft Office Excel. Metoda kompilacije korištena je u teorijskom djelu rada, gdje su objedinjeni rezultati istraživanja referentnih autora.

\section{ANALIZA STANJA STRUČNOG OSPOSOBLJAVANJA RADNIKA U SEKTORU ŠUMARSTVA \\ SITUATION ANALYSIS OF WORKERS VOCATIONAL TRAINING IN FORESTRY SECTOR}

Zahtjevi i okvirni uvjeti osposobljavanja i obuke u šumarstvu Europe znatno su se promijenili u posljednjih 15 godina. Tri glavna područja promjena mogu se promatrati kroz (a) promjene u društveno-ekonomskom okruženju s utjecajem na sadržaj obuke, (b) promjene u tehnološkom okruženju s utjecajima na korištenje sredstava rada i predmeta specijalizacije i (c) promjene u sustavima osposobljavanja kroz temeljne reforme kako se provode, npr. Kopenhagenski proces (Bernasconi i Schroff, 2011). Dodatni simultani utjecaj na navedene promjene imali su progresivni procesi internacionalizacije i globalizacije.
Kopenhaški proces temeljen na Kopenhagenskoj deklaraciji iz 2002. godine zagovara jačanje i popularizaciju stručnog obrazovanja i obuke. Proces predstavlja obrazovno-političku i prema radnicima-tržištu orijentiranu strategiju za unapređenje izvedbe, kvalitete i atraktivnosti strukovnog obrazovanja i osposobljavanja. Navedeno ima za cilj promicanje veće međunarodne suradnje u strukovnom obrazovanju i osposobljavanju te na mobilnosti, propusnosti, usporedivosti i transparentnosti općeg i strukovnog obrazovanja i osposobljavanja kroz proces cijeloživotnog učenja i podrške na tržištu rada (BBT 2009).

U Europskom šumarskom okruženju postoji značajan niz mreža i programa (tablica 1) koji se bave problematikom tečajeva, kvalifikacija i sadržaja osposobljavanja u šumarstvu.

Sa gledišta osposobljavanja i usavršavanja ljudskih resursa za održivo gospodarenje šumama, značajan doprinos unutar EU okruženja ima Eduforest internet platforma (tablica 1) koja je pokrenuta 1998. godine u okviru »Leonardo da Vinci« programa poduprtog od strane Europske komisije. Ključni ciljevi Eduforest mreže su (a) promicanje cjeloživotnog osposobljavanja, (b) promicanje karijera u sektoru šumarstva razvojem kompetencija i (c) promicanje razmjene svega što može promovirati osposobljavanje i zapošljavanje u šumarstvu. Pretraživanjem baze Eduforest mreže (zaključno sa danom 3. lipnjem 2016. godine) utvrđeno je 97 institucija registriranih za obrazovanje/osposobljavanje u šumarstvu (srednjih škola, instituta, fakulteta, centara za obrazovanje i sl.) iz 20 različitih zemalja svijeta (slika 1). Najveći broj registriranih obrazovnih institucija $(\mathrm{N}=91)$ dolazi iz zemalja članica EU. 


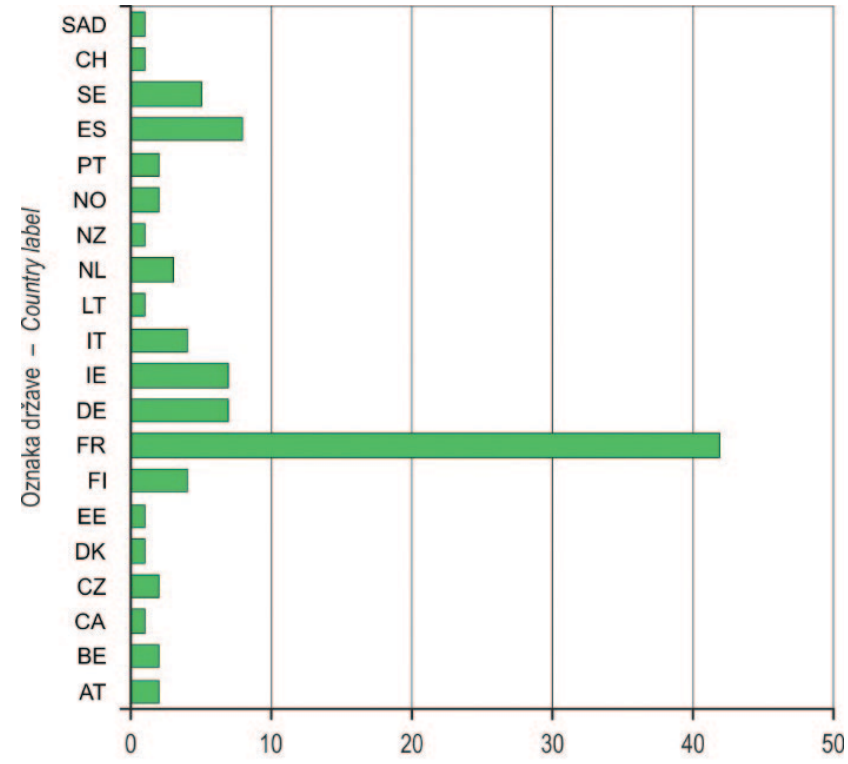

Broj registriranih ustanova - The number of registered institutions

Slika 1. Registar obrazovnih institucija Eduforest mreže (Austrija - AT, Belgija - BE, Kanada - CA, Ceška - CZ, Danska - DK, Estonija - EE, Finska - FI, Francuska - FR, Njemačka - DE, Irska - IE, Italija - IT, Litva - LT, Nizozemska - NL, Novi Zeland - NZ, Norveška - NO, Portugal PT, Španjolska - ES, Švedska - SE, Švicarska - CH, Sjedinjene Američke Države - SAD)

Figure 2 Eduforest network register of educational institutions (Austria AT Belgium - BE, Canada - CA, Czech Republic - Czech Republic, Denmark - DK, Estonia - EE, Finland - Fl, France - FR, Germany - DE, Ireland - IE, Italy - IT, Lithuania - LT, Netherlands - NL, New Zealand - NZ, Norway NO, Portugal - PT, Spain - ES, Sweden - SE, Switzerland - CH, United States - USA)

Registracija obrazovnih institucija u bazi Eduforest mreže provedena je na osnovi (a) vrste osposobljavanja koje provode (stručno, za odrasle, tehničko, profesionalno i sveučilišno), a spram (b) ciljane skupine (radnik, nadzornik, menadžer / inženjer i poduzetnik) (slika 2). Pod profesionalnim osposobljavanjem podrazumijeva se odrađivanje pripravničkog staža unutar poduzeća. Stručno osposobljavanje ima za cilj pružiti znanje, vještine i stavove koji su potrebni za učinkovito i kvalitetno izvršavanje radnih zadataka, a u šumarstvu ima za cilj pružiti specijalizirane vještine koje zahtijeva npr. radno mjesto šumskog radnika (sjekač, rukovatelj šumske mehanizacije) i poslovođe/nadzornika. Tehničko osposobljavanje podrazumijeva srednjoškolsko i visokoškolsko obrazovanje teorijskog predznaka. Osposobljavanje odraslih podrazumijeva dopunsko obrazovanje zaposlenika u šumarstvu, kako bi se zadovoljili zahtjevi poduzeća i stekle komplementarne kompetencije zaposlenika, dok sveučilišno osposobljavanje podrazumijeva obrazovanje koje rezultira kvalifikacijom inženjera. Analizom i sintezom te komparacijom podataka (slika 2) vidljivo je da značajan broj registriranih institucija u Eduforest mreži (preko 50 \%) pruža stručno osposobljavanje i osposobljavanje odraslih za poslove radnika i nadzornika, dok je tehničko i profesionalno osposobljavanje zastupljeno preko $40 \%$. Zanimljiv

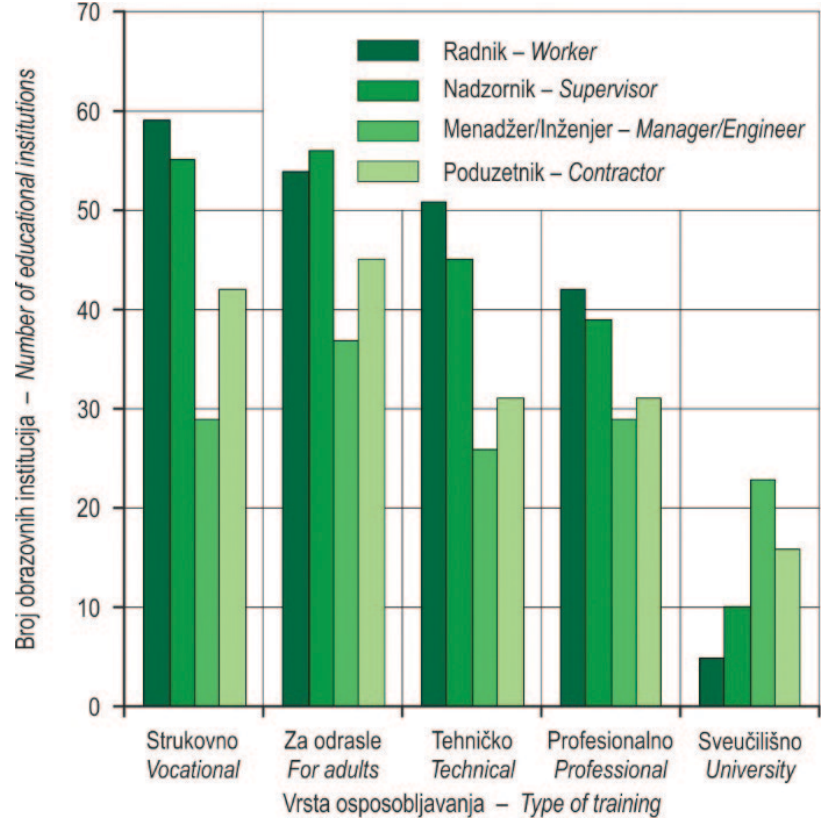

Slika 2. Udio tipa osposobljavanja spram ciljanih skupina pri registriranim institucijama u Eduforest mreži

Figure 2 Share type of training towards the target group of registered institutions in Eduforest network

rezultat istraživanja odnosi se na sveučilišno osposobljavanje radnika i nadzornika (slika 2). Navedeno podrazumijeva razvijene module usavršavanja i specijalizacije radnika, nadzornika i poduzetnika u okviru akademskih programa, što su dodatno u rezultatima istraživanja istaknuli Bernasconi i Schroff (2011), gdje navode adaptivnost i propusnost šumarske obuke s ciljem daljnjeg usavršavanja u Irskoj, Belgiji, Švicarskoj, Njemačkoj. Kod kategorije poduzetnika te menadžera/inženjera (slika 2) najzastupljenije je osposobljavanje odraslih, a zatim slijedi stručno i profesionalno osposobljavanje.

\subsection{Uloga stručnog osposobljavanja radnika u šumarstvu - The role of vocational training of workers in forestry}

Stručno osposobljavanje ima ključno značenje kod izvođenja radnih operacija u šumarstvu. Doprinos stručnog osposobljavanja dokumentiran je s obzirom na koristi kod održivog gospodarenja šumama i povećanje stope produktivnosti (Tsioras i Efthymiou 2007) te veće kvalitete kod izvođenja šumskih radova (Tsioras 2010). Amortizacija osposobljavanja može biti vrlo brza, a ostvaruje se kroz veće stope produktivnosti u razdoblju nakon provedenog osposobljavanja (Garland 1990). S druge strane, neosposobljeni šumski radnici oslanjaju se na stečeno iskustvo tijekom rada na konkretnom radnom mjestu. Tako usvojeno znanje je nesustavno i slučajno, ali isto se može nadopuniti i nadograditi kroz sustavnu izobrazbu odraslih (Tsioras 2012). Danas stručno osposobljavanje predstavlja osnovni preduvjet suvremenog šumarstva, gdje se tradicionalni šumski radnik 
sjekač može prevesti u kompetentnog suradnika u gospodarenju šumskim resursima.

Razina sigurnosti pri šumskom radu ima neizmjernu korist od provođenja stručnog osposobljavanja radnika u šumarstvu (Smith i Thomas 1993). Statistike potvrđuju da se stručno osposobljeni radnici manje ozljeđuju (Axelsson 1998, Stadlmann 1997) i rjeđe smrtno stradavaju. Već na samome početku osposobljavanja polaznici počinju shvaćati važnost istog i razvijaju kulturu sigurnosti, krenuvši od konstantne uporabe osobne zaštitne opreme prema naprednijim sigurnosnim pitanjima, kao što je uporaba odgovarajuće tehnike rušenja vjetrom oštećenih stabala na nagnutom terenu i sl. (Tsioras 2012).

U kontekstu sadašnjeg trenda stručnog osposobljavanja važno je istaknuti modularizaciju obuke i uvođenje specijalizacije. Tijekom posljednja dva desetljeća, specijalizirani tečajevi razvijeni su u mnogim zemljama, gdje šumski radnici sjekači i operateri šumske mehanizacije predstavljaju važnu i često ciljnu skupinu za takav oblik specijalizacije. Veća pozornost je data poduzetničkom i ekonomskom aspektu kod dizajna programa edukacije. Sadržaji kolegija prilagođeni su društvenim i tehničkim dostignućima uz izraženiji naglasak na jezičnim vještinama, unapređenju poduzetničkih kvalifikacija, povećanju kompetencija u području mehanizacije i logistike te širenja metodoloških sposobnosti. Paralelno s navedenim, potreba za certifikacijom programa osposobljavanja, a time također ispitivanje vještina stečenih tijekom obuke, dobilo je na važnosti. U Njemačkoj, stari » Waldarbeiterschulen « (šumarske škole) su se razvili u centre za osposobljavanje u šumarstvu, te su uvedene stručne dozvole tj. profesionalni certifikati za obrazovanje i osposobljavanje, npr. u Francuskoj, Austriji (slika 3), Njemačkoj (Bernasconi i Schroff, 2011).
Pozitivan iskorak stručnog osposobljavanja radnika u šumarstvu na razini Europe dogodio se 2009. godine kroz osnivanje Vijeća za europsko šumarstvo i okolišne vještine (European Forestry and Environmental Skills Council EFESC) čija misija je pojednostaviti mobilnost radnika u šumarstvu i arborikulturi unutar EU kroz procese akreditacije i promicanja individualnih nacionalnih kvalifikacija između partnerskih zemalja na europskoj razini. Pozadinski motiv osnivanja EFESC-a bio je razvoj univerzalnog europskog kvalifikacijskog standarda za rad s motornom pilom s ciljem: (a) smanjenja ozljeda na radu i nesreća sa smrtnim ishodom, (b) smanjenja popratnih ekonomskih i osobnih troškova povezanih s ozljedom na radu, (c) poboljšanja i unaprjeđenja vještina te učinkovitosti rukovatelja radnog sredstva, (d) poboljšanja mobilnosti i zapošljavanja rukovatelja na razini Europe, (e) unaprjeđenja i proširenja postojećih programa stručnog osposobljavanja i vrednovanja standarda te (f) poticanja i promicanja cijeloživotnog učenja uz kontinuirano stručno usavršavanje (izvor: http:// www.europeanchainsaw.eu/). Detaljniji uvid u rad EFESCa te razvoj i implementaciju europskog standarda za rukovatelja motornom pilom (European Chainsaw Standards $E C S)$ na razini EU prikazan je unutar podnaslova $3.3 \mathrm{u}$ okviru ovoga rada.

\subsection{Aktualno stanje stručnog osposobljavanja radnika sjekača u šumarstvu Hrvatske - Current condition on vocational training for chainsaw operator in the forestry of Croatia}

Mjere sigurnosti i pravila zaštite na radu kod profesionalnog bavljenja šumskim radovima u Republici Hrvatskoj propisani su Pravilnikom o zaštiti na radu u šumarstvu (N.N. 10/86). S druge strane, Zakonom o šumama (N.N.
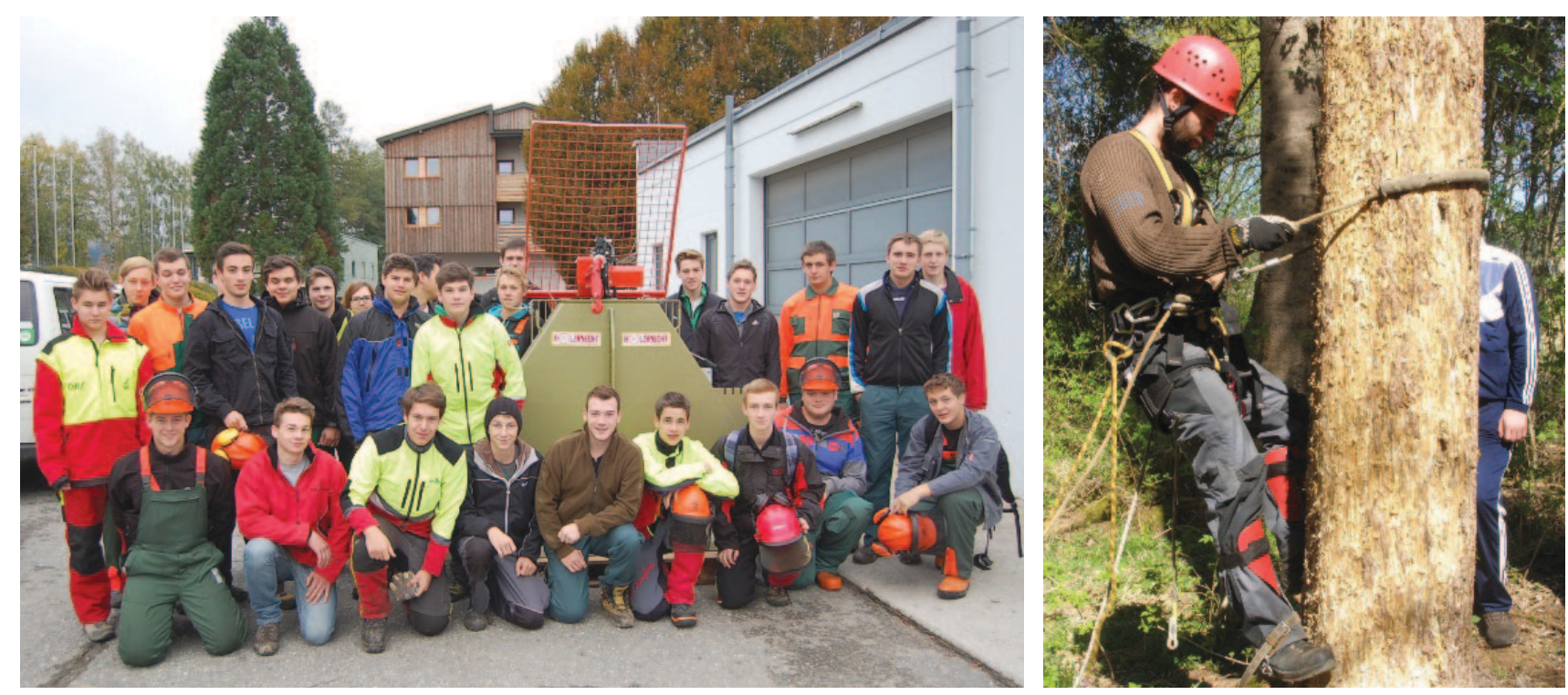

Slika 3. Polaznici tečaja šumarskog centara za osposobljavanje Ossiach, Austrija

Figure 3 The course participants of the forestry training center Ossiach, Austria 
94/14) neprofesionalcima (lokalnom stanovništvu i šumovlasnicima) koji su osposobljeni za radove pridobivanja drva dozvoljava iz šume za vlastite potrebe izradu do $20 \mathrm{~m}^{3}$ godišnje ogrjeva (samoizradbu) uz dozvolu i pod nadzorom osobe koja gospodari tim šumama. Navedeni radovi samoizradbe, kao tradicionalna posebnost hrvatskog šumarstva, godišnje dosežu količinu do $650.000 \mathrm{~m}^{3}$ (Godišnje poslovno izvješće HŠ, 2015), što kada se stavi u odnos s količinom ogrjeva za vlastite potrebe pojedinca čini tisuće potencijalnih aktera koji trebaju biti osposobljeni za rad na siguran način i za rad sa radnim sredstvom prema verificiranom programu. Manjkavost zakonskog propisa čini nejasnu slika vezano za razinu kvalifikacije i vrstu osposobljenosti koju neprofesionalci moraju zadovoljiti, te kvalificiranost nadzornog osoblja kada se radovi pridobivanja drva provode u privatnoj šumi. Sukladno navedenomu, a vezano za standarde obuke i sadržaj osposobljavanja šumskog radnika sjekača za rad na siguran način, prema Martiniću i Landekiću (2012), u Hrvatskoj danas postoji veći broj programa osposobljavanja različitih organizatora i nositelja u obliku seminara i tečajeva. Prema istim autorima čak 65 pravnih osoba posjeduje potrebno ovlaštenje i provodi navedeno osposobljavanje. Osnovni uvjet za polaznike kod osposobljavanja za upravljanje i rukovanje motornim pilama je završena osnovna škola polaznika, starosna dob (stariji od 18 godina), te zadovoljavanje zdravstvenih i psihičkih sposobnosti za obavljanje navedenih radnih aktivnosti.

Organizacijski oblik osposobljavanja rukovatelja motornom pilom, u pravilu sadrži, redovitu (R) ili konzultativno - instruktivnu (K-I) nastavu koja se sastoji iz teoretskog i praktičnog dijela. Osposobljavanje se provodi u trajanju od 20 sati teoretske nastave (redovita nastava ili konzultativno instruktivne) i 60 sati praktičnog rada. Voditelj osposobljavanja u dogovoru s naručiteljem osposobljavanja, vodeći računa o predznanju polaznika, određuje model organizacije i izvođenja nastave. Polazniku osposobljavanja, u dijelu programa ili u cjelini, proporcionalno se skraćuje trajanje obrazovanja ukoliko ispitom dokaže stečeno znanje iz praktične nastave i vježbi (izvor: http://obrazovanje.vss.hr/). Na pisani zahtjev polaznika i uz priložene dokaze (potvrda tvrtke gdje je obavljao praksu) stečeno znanje i vještine iz praktične nastave i vježbi ocjenjuje se pred tročlanim povjerenstvom u skladu s čl. 32. Pravilnika o standardima $i$ normativima te načinu i postupku utvrdivanja ispunjenosti uvjeta u ustanovama za obrazovanje odraslih (N.N. 129/08).

Iz dosadašnje prakse uočeno je da su najveći problemi osposobljavanja vezani za: (a) neujednačene i necjelovite programe i sadržaje osposobljavanja, (b) značajnu redukciju, pa i izostanak praktičnog dijela obuke i (c) primjenu netransparentnih kriterija kod ocjenjivanja provedene obuke (Martinić i dr. 2011, MZOŠ projekt 2013). Drugi korak osposobljavanja kod šumskog radnika sjekača podrazumijeva osposobljavanje radnika za rad na siguran način s radnim sredstvom unutar radnog okruženja. U okviru plana i programa osposobljavanja ovlaštenika poslodavca III. (poslovođe) i IV. stupnja (radnika), u trgovačkom društvu HŠ d.o.o. Zagreb, osposobljavanje se provodi u trajanju od 7 sati teoretske nastave i minimalno 1 sata praktičnog rada (demonstracija sigurnog i pravilnog rada na rušenju stabala).

Dobar primjer iskoraka u strukovnom obrazovanja radnika u hrvatskom šumarstvu rezultat je udruženog rada Agencije za strukovno obrazovanje i obrazovanje odraslih te Ministarstva znanosti, obrazovanja i sporta koji je rezultirao 2011. godine izrađenim nastavnim planom i programom tj. strukovnim kurikulumom te standardom zanimanja i kvalifikacije »šumar « koji traje 3 godine. Navedeni standard zanimanja i kvalifikacije predstavlja univerzalnog šumskog radnika koji (a) samostalno i pod nadzorom obavlja poslove u uzgajanju, zaštiti i uređivanju šuma, šumskom građevinarstvu i lovstvu; (b) odgovorno i sigurno obavlja poslove u postupku pridobivanja drvnih sortimenata i ostalih (sporednih) šumskih proizvoda te (c) upravlja specijaliziranim šumskim strojevima, ručnim alatima, uređajima i napravama koje se koriste u šumarstvu, te održava iste (MZOŠ 2011).

\subsection{Uloga i doprinos Vijeća za europsko šumarstvo i okolišne vještine u procesu osposobljavanja radnika - The role and contribution of the European forestry and environmental skills council in the training of workers}

Unatrag sedam godina u EU je razvijena ideja da standardi obuke i sadržaj osposobljavanja izvoditelja šumskih radova budu razvijeni i certificirani na europskoj razini. To je ponajprije povezano sa slobodom pružanja usluga koja je unutar EU gotovo svakodnevna pojava (npr. za velik broj poduzeća/radnika koji rade izvan svoje zemlje u slučaju elementarnih nepogoda - vjetrolom, ledolom, snjegolom i dr.). Za operativnu provedbu sustava certifikacije radnih kompetencija i vještina zaduženo je Vijeće za europsko šumarstvo i okolišne vještine (EFESC) koje je osnovano 2009. godine od strane članova »Leonardo da Vinci« projekta, a odobrenjem EFESC priručnika 2012. godine organizacija je i službeno osnovana (izvor: http://www.europeanchainsaw.eu/). EFESC je inicijativa stručnjaka iz centara za obuku $\mathrm{u}$ šumarstvu te industrije kojem je namijenjena uloga krovne organizacije za upravljanje certificiranim standardima osposobljavanja, koji su prihvaćeni od strane cijele industrije (slika 4). Organizacijska struktura EFESC je sastavljena od različitih tijela (kao npr. Opće skupštine, Izvršnog odbora, Odbora za standarde, Akreditacijskog odbora te Tajništva kojem je domaćin KWF u Njemačkoj). Opću skupštinu čine svi članovi EFESC-a te isti biraju Izvršni odbor koji je odgovoran za provedbu politike EFESC-a. Odbor za standarde izrađuje i ažurira EFESC standarde koji se kasnije odobravaju od strane Opće skupštine. Akreditacijski odbor definira, te održava postupak akreditacije i revizije 


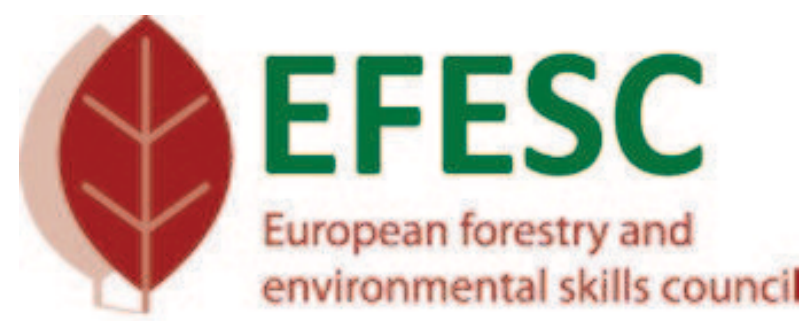

Slika 4. Logotip Vijeća za europsko šumarstvo i okolišne vještine

Figure 4 The logo of the European forestry and environmental skills council

unutar EFESC. Također, isti provjerava zahtjev kandidata koji žele djelovati kao nacionalna agencija te sugerira provođenje postupka akreditacije Izvršnom odboru (izvor: http://www.europeanchainsaw.eu/).

Prvi minimalni standard razvijen pod okriljem EFESC-a, parcijalno implementiran u zemljama članicama EU, je europski standard za motornu pilu (European Chainsaw Standards - ECS) koji se sastoji od četiri različite razine. Razvijeni standard nije zakonski obvezujući, već predstavlja skup minimalnih standarda koji se smatraju »najboljom praksom « kod profesionalne i/ili polu-profesionalne uporabe motorne pile, a fokus je usmjeren na tehničko sigurnosni aspekt uporabe sredstva rada. U provedbi certifikacije minimalnih radnih kompetencija, tj. odobravanja i revidiranja (kontroliranja) nacionalnih pružatelja osposobljavanja, EFESC se oslanja na nacionalne centre koji kroz postupak akreditacije izdaju dopusnicu za certificiranje programa os- posobljavanja dotičnom centru/instituciji za osposobljavanje i obuku. Temeljem dobivene dopusnice centri/institucije tj. pružatelji osposobljavanja na svoju ruku mogu koristiti ECC certifikat i/ili mogu koristiti ECC logotip (slika 5) na svom certifikatu, ako su u skladu s kriterijima koje je postavilo Vijeće EFESC-a, a revidirala i odobrila nacionalna agencija.

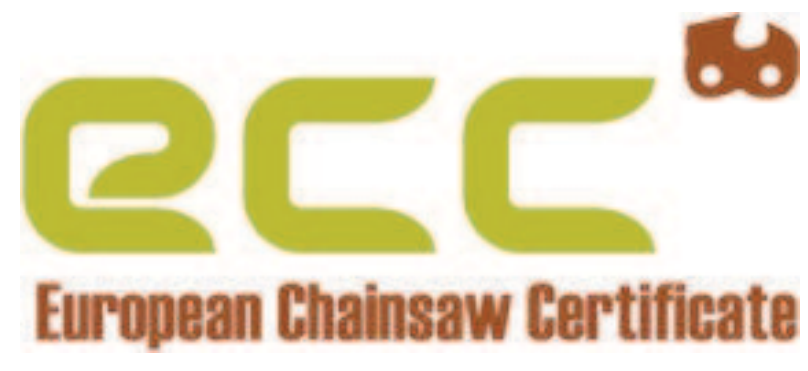

Slika 5. Logotip europskog standarda za rukovatelja motornom pilom Figure 5 The logo of the European chainsaw certificate

Status nacionalnog centra/agencije može dobiti centar za osposobljavanje u šumarstvu, pojedino profesionalno poduzeće ili neka od vladinih organizacija. Kriteriji za dobivanje statusa nacionalnog centra/agencije propisani su u Priručniku EFESC-a, a sastoje se od sedam ključnih uvjeta:

I. organizacija treba biti dobro integrirana unutar nacionalnog razvoja tj. mora predstavljati razne interesne organizacije u šumarskom sektoru;

Tablica 2. Popis nacionalnih agencija akreditiranih od strane EFESC-a Table 2 The list of national agencies accredited by the EFESC

\begin{tabular}{|c|c|c|}
\hline $\begin{array}{l}\text { Zemlja } \\
\text { Country }\end{array}$ & $\begin{array}{l}\text { Naziv institucije } \\
\text { Name of institution }\end{array}$ & $\begin{array}{l}\text { Opis institucije } \\
\text { Description of the institution }\end{array}$ \\
\hline $\begin{array}{l}\text { Belgija } \\
\text { Belgium }\end{array}$ & Inverde & $\begin{array}{l}\text { - je mrežna platforma za zelene ekspertize za Vladu i za zeleni sektor } \\
\text { - is the forum for green expertise both for the Government and for the green sector }\end{array}$ \\
\hline $\begin{array}{l}\text { Španjolska } \\
\text { Spain }\end{array}$ & $\begin{array}{l}\text { Forest Sciences Centre of } \\
\text { Catalonia }\end{array}$ & $\begin{array}{l}\text { - je udruženje } 6 \text { lokalnih i regionalnih institucija (npr. Katalonske zaklade za istraživanja } \\
\text { i inovacije, Lleida Sveučilišta itd.) } \\
\text { - is consortium of } 6 \text { local and regional institutions (e.g. Catalan Foundation for } \\
\text { Research and Innovation, University of Lleida ect.) }\end{array}$ \\
\hline $\begin{array}{l}\text { Nizozemska } \\
\text { Netherlands }\end{array}$ & IPC Groene Ruimte & $\begin{array}{l}\text { - je strukovni centar za obuku } \\
\text { - is Vocational Training Centre }\end{array}$ \\
\hline $\begin{array}{l}\text { Francuska } \\
\text { France }\end{array}$ & $\begin{array}{l}\text { Centre Forestier de la Bastide les } \\
\text { Jourdans }\end{array}$ & $\begin{array}{l}\text { - je šumarski centar za obuku i osposobljavanje } \\
\text { - is forestry training centre }\end{array}$ \\
\hline $\begin{array}{l}\text { Austrija } \\
\text { Austria }\end{array}$ & $\begin{array}{l}\text { Bundesministerium für Landwirt- } \\
\text { schaft, Forsten und Umwelt }\end{array}$ & $\begin{array}{l}\text { - je Federalno ministarstvo poljoprivrede, šumarstva i okoliša } \\
\text { - The Federal Ministry of Agriculture, Forestry and Environment }\end{array}$ \\
\hline $\begin{array}{l}\text { Njemačka } \\
\text { Germany }\end{array}$ & $\begin{array}{l}\text { Kuratorium für Waldarbeit und } \\
\text { Forsttechnik }\end{array}$ & $\begin{array}{l}\text { - je Upravni odbor za šumarstvo i šumske tehnologije } \\
\text { - is the Board of Forestry and Forestry Technology }\end{array}$ \\
\hline $\begin{array}{l}\text { Italija } \\
\text { Italy }\end{array}$ & Efesc Italia Onlus & $\begin{array}{l}\text { - je talijanska EFESC organizacija osnovana od strane } 13 \text { institucija heterogenog } \\
\text { podrijetla } \\
\text { - is Italian FESC organization founded by } 13 \text { institutions heterogeneous origin }\end{array}$ \\
\hline $\begin{array}{l}\text { Rumunjska } \\
\text { Romania }\end{array}$ & $\begin{array}{l}\text { Centrul de Pregatire si perfecti- } \\
\text { onare profesionala Roznov }\end{array}$ & $\begin{array}{l}\text { - je centar za obuku i stručno usavršavanje (registriran kao tvrtka). } \\
\text { - is a center for training and professional development (registered as a company). }\end{array}$ \\
\hline $\begin{array}{l}\text { Ujedinjeno Kraljevstvo } \\
\text { United Kingdom }\end{array}$ & City \& Guilds & $\begin{array}{l}\text { - je globalni tržišni lider u izobrazbi vještina. } \\
\text { - is a global market leader in skills education. }\end{array}$ \\
\hline
\end{tabular}




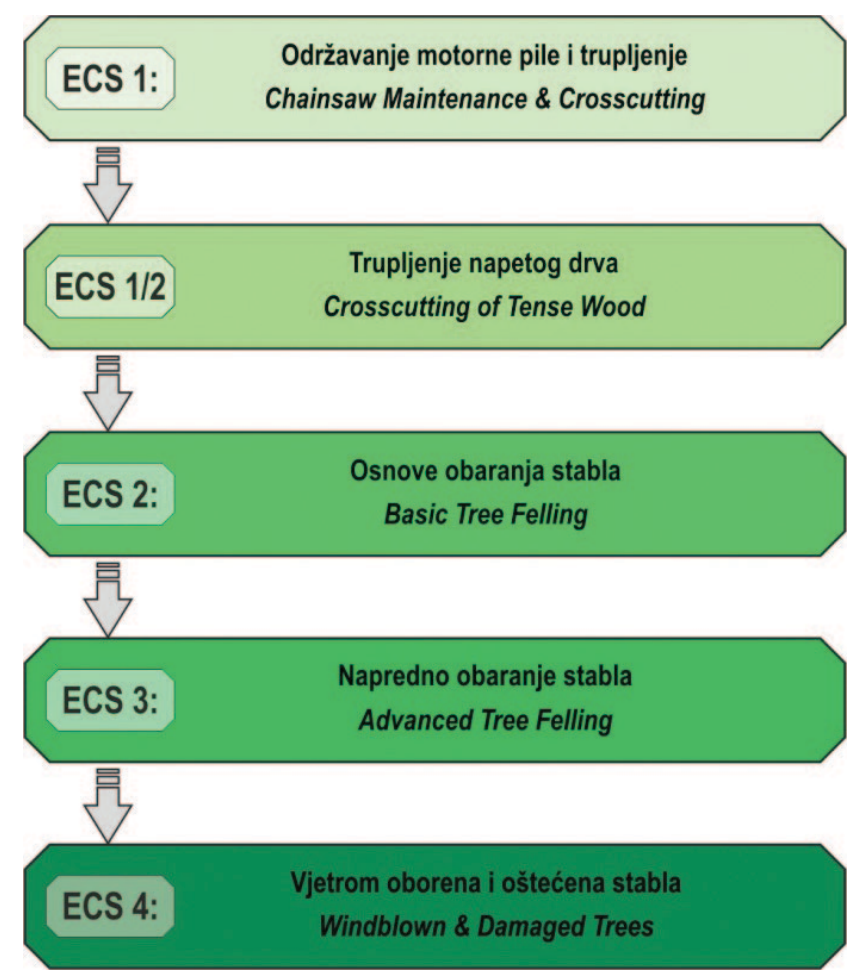

Slika 6. Razine europskog standarda za rukovatelja motornom pilom Figure 6 Levels of European chainsaw standards

II. organizacija mora imati pravnu osobnost;

III. organizacija mora imati adekvatan broj zaposlenika ili imati pristup ljudskim resursima, kako bi djelovali u ulozi facilitatora/podupirućeg organizatora;

IV. organizacija mora raspolagati ili imati pristup kvalificiranom osoblju;

V. organizacija mora imati sustav osiguranja kvalitete;

VI. organizacija mora pristati na EFESC standarde;
VII. organizacija mora imati iskustvo u obuci i/ili u certifikaciji vještina vezanih za rukovanje motornom pilom (izvor: EFESC Handbook 2015).

Zaključno sa rujnom 2016. godine unutar Europe imamo 9 akreditiranih nacionalnih centara u devet različitih zemalja (tablica 2). Iz tablice 2 vidljivo je da akreditirani nacionalni centri/agencije imaju različite pravno ustrojbene oblike; od gospodarskih udruženja, centara za obuku i mrežnih platforma do ministarstva i ostalih organa državne uprave.

\subsubsection{Implementacija europskog standarda za motornu pilu - The implementation of the European chainsaw standards}

U suradnji s centrima za obuku, centrima za ocjenjivanje i certifikatorima diljem Europe (Austrija, Belgija, Danska, Njemačka, Francuska itd.) pet razina minimalnih standarda »najbolje prakse« za rukovanje motornom pilom su razvijene u detalje (slika 6), te su isti pregledani i testirani od strane međunarodnog tima trenera rada s motornom pilom i ocjenjivača.

Prva razina europskog standarda za motornu pilu (ECS 1), prikazana na slici 6., odnosi se na uvod u rukovanje motornom pilom, a sadrži: (a) osnovna zdravstvena i sigurnosna pitanja vezana za rukovatelja; (b) postupak redovitog održavanja motorne pile i dnevne inspekcije; (c) trupljenje debla manjeg srednjeg promjera uz pravilno i na siguran način korištenje pomoćnih alata kod pomicanja i/ili podizanja izrađenog oblog drva te (d) slaganje i rukovanje sa izrađenim drvnim sortimentima. Novo formirana razina "napeto drvo« (ECS 1/2) odnosi se na savladavanje tehnike trupljenja drvnih sortimenata prema vlačnim i tlačnim silama (napeto drva s gornje ili donje strane te bočno napeto drvo).

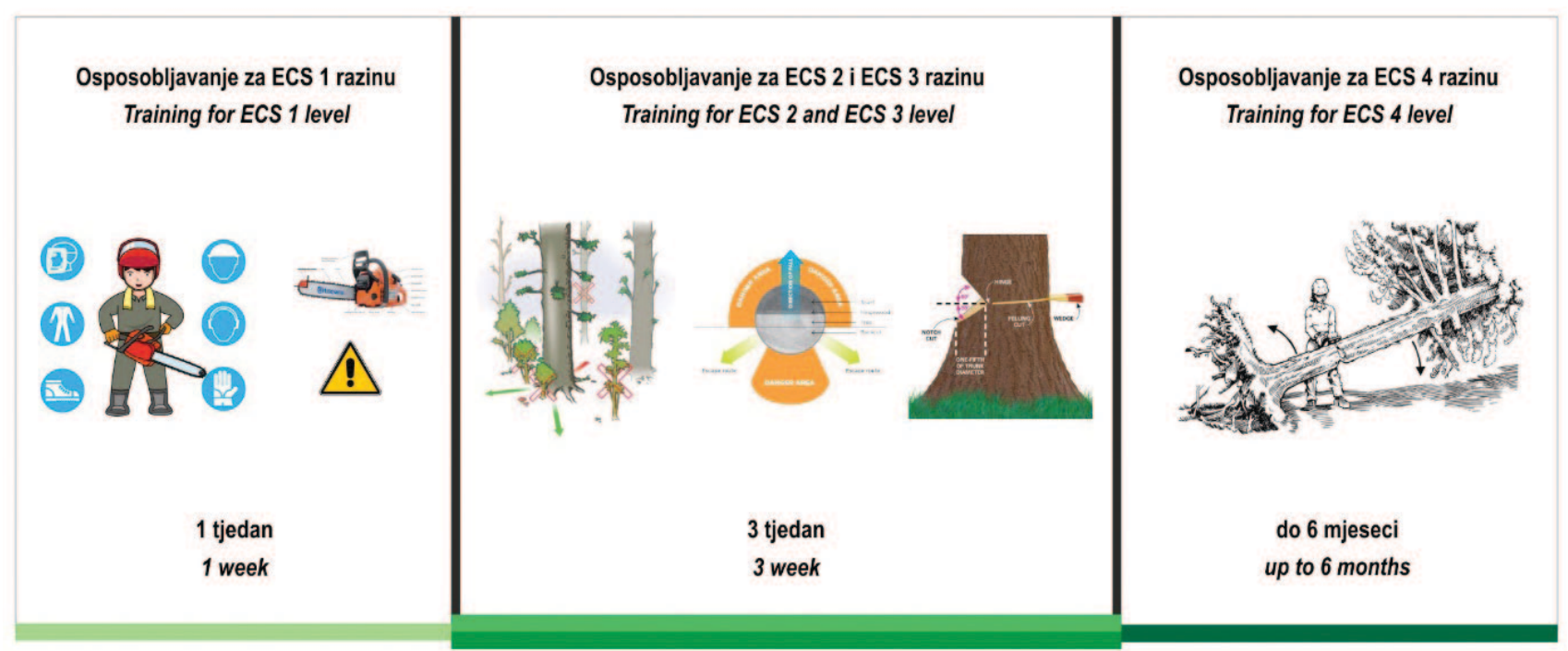

Slika 7. Njemački primjer implementacije europskog standarda za rukovatelja motornom pilom

Figure 7 German example of the European chainsaw standards implementation 
Tablica 3. Implementacija europskog standarda za rukovatelja motornom pilom unutar zemalja članica EFESC-a Table 3 The implementation of European chainsaw standards within EFESC countries

\begin{tabular}{|c|c|c|c|c|c|c|c|c|}
\hline & \multicolumn{8}{|c|}{ Zemlja - Country } \\
\hline & $\begin{array}{l}\text { Austrija } \\
\text { Austria }\end{array}$ & $\begin{array}{l}\text { Belgija } \\
\text { Belgium }\end{array}$ & $\begin{array}{l}\text { Francuska } \\
\text { France }\end{array}$ & $\begin{array}{l}\text { Italija } \\
\text { Italy }\end{array}$ & $\begin{array}{l}\text { Nizozemska } \\
\text { Netherlands }\end{array}$ & $\begin{array}{l}\text { Njemačka } \\
\text { Germany }\end{array}$ & $\begin{array}{l}\text { Rumunjska } \\
\text { Romania }\end{array}$ & $\begin{array}{l}\text { Španjolska } \\
\text { Spain }\end{array}$ \\
\hline $\begin{array}{l}\text { Godina početka } \\
\text { implementacije } \\
\text { Starting year of } \\
\text { implementation }\end{array}$ & $\begin{array}{l}\text { Od } 2015 . \\
\text { Form } 2015\end{array}$ & $\begin{array}{l}\text { Od } 2012 . \\
\text { Form } 2012\end{array}$ & $\begin{array}{l}\text { Od } 2015 . \\
\text { Form } 2015\end{array}$ & $\begin{array}{l}\text { Od } 2015 . \\
\text { Form } 2015\end{array}$ & $\begin{array}{l}\text { Od } 2014 . \\
\text { Form } 2014\end{array}$ & $\begin{array}{l}\text { Od } 2014 . \\
\text { Form } 2014\end{array}$ & $\begin{array}{l}\text { Od } 2015 . \\
\text { Form } 2015\end{array}$ & $\begin{array}{l}\text { Od } 2015 . \\
\text { Form } 2015\end{array}$ \\
\hline $\begin{array}{l}\text { Broj centara za } \\
\text { ocjenjivanje } \\
\text { Number of } \\
\text { Assessment centres }\end{array}$ & 3 & 2 & 12 & 7 & 1 & 2 & 1 & 1 \\
\hline $\begin{array}{l}\text { Broj nositelja } \\
\text { certifikata* } \\
\text { Number of } \\
\text { certificate holders* }\end{array}$ & 152 & 645 & 124 & 35 & 83 & 474 & 170 & 118 \\
\hline $\begin{array}{l}\text { Broj izdanih } \\
\text { certifikata } \\
\text { Number of } \\
\text { certificates issued }\end{array}$ & $\begin{array}{l}\text { ECS } 1=152 \\
\text { ECS } 2=152 \\
\text { ECS } 3=152 \\
\text { ECS } 4=115\end{array}$ & $\begin{array}{l}\operatorname{ECS} 1=645 \\
\operatorname{ECS} 2=209 \\
\operatorname{ECS~} 3=31 \\
\operatorname{ECS~} 4=6\end{array}$ & $\begin{array}{l}\operatorname{ECS} 1=124 \\
\operatorname{ECS} 2=73 \\
\operatorname{ECS} 3=9\end{array}$ & $\begin{array}{l}\operatorname{ECS} 1=30 \\
\operatorname{ECS} 2=9 \\
\operatorname{ECS} 3=13\end{array}$ & $\begin{array}{l}\operatorname{ECS} 1=83 \\
\operatorname{ECS} 2=56 \\
\operatorname{ECS} 3=15\end{array}$ & $\begin{array}{l}\text { ECS } 1=474 \\
\text { ECS } 2=462 ; \\
\text { ECS } 3=462 ; \\
\text { ECS } 4=433\end{array}$ & $\begin{array}{l}\operatorname{ECS~} 1=170 \\
\operatorname{ECS} 2=170 \\
\operatorname{ECS} 3=169\end{array}$ & $\begin{array}{c}\operatorname{ECS} 1=117 \\
\operatorname{ECS} 2=68 \\
\operatorname{ECS} 3=9\end{array}$ \\
\hline $\begin{array}{l}\text { Broj certificiranih } \\
\text { ocjenjivača } \\
\text { Number of certified } \\
\text { assessors }\end{array}$ & 5 & 14 & 44 & 18 & 5 & 28 & 1 & 4 \\
\hline
\end{tabular}

Druga razina (ECS 2) predstavlja proširenu osnovu rukovanja motornom pilom (slika 6), a sadrži: (a) rušenje uspravnih i nagnutih stabala manjeg prsnog promjera raznim tehnikama rušenja, (b) oslobađanje/uklanjanje zaustavljenih stabala (zaustava) pomoću ručnih alata, (c) kresanje grana i trupljenje debla te (d) na siguran način slaganje i rukovanje izrađenim drvnim sortimentima. Treća razina (ECS 3) pogodnija je za rukovatelje s više radnog iskustva s motornom pilom (slika 6), a sadrži: (a) rušenje stabala srednjeg i većeg prsnog promjera naprednijim tehnikama rušenja te (b) kresanje velikih grana i upotreba adekvatne opreme za spuštanje zaustava, uključujući metode uklanjanja. Četvrta razina (ECS 4) pogodna je za izrazito iskusne šumske radnike sjekače, a sadrži: (a) tehniku saniranja korijenovog sustava, (b) tehniku odvajanja debla od korijena kod izvaljenih stabala, (c) rušenje izraženo nagnutih i djelomično izvaljenih stabala te (d) rušenje stabala sa polomljenom krošnjom (izvor: http://www.europeanchainsaw.eu/certificate). Na slici 7. prikazan je njemački primjer implementacije i vremensko trajanje osposobljavanja prema europskom standardu za rukovatelja motornom pilom.

U tablici 3. prikazan je, zaključno sa studenim 2016. godine, proces implementacije novog koncepta osposobljavanja tj. univerzalnog europskog standarda za motornu pilu unutar zemalja koje imaju akreditirane nacionalne agencije od strane EFESC-a. Iz tablice je vidljivo da su Belgija i Njemačka izdale najveći broj certifikata, a zatim slijedi Španjol- ska, Austrija i Rumunjska. Najmanji broj izdanih certifikata zabilježen je kod Italije i Nizozemske.

Europski certifikat za rukovatelja motornom pilom nije zakonski obvezujući niti za profesionalce niti za pojedince (neprofesionalce, amatere) koji motornu pilu koriste povremeno. Navedeni standard je sukladan s aspektom kvalitete i kakvoće rada te sigurnosti pri šumskom radu, a potreba implementacije navedenog standarda i sustava certifikacije šumskog radnika sjekača obrazlaže se sljedećim:

transparentnost vještina i kompetencija kroz detaljan opis potrebnih kvalifikacija za svaku razinu (slika 6),

poboljšana mobilnost i zapošljivost rukovatelja motornom pilom u cijeloj Europi pomoću jedinstvenog certifikata koji jamči za vještine i kompetencije vlasnika certifikata, neovisno o jeziku i zemlji,

kvaliteta i sljedivost licenciranih nositelja certifikata putem registra europske organizacije EFSC (izvor: http:// www.europeanchainsaw.eu/).

\section{RASPRAVA I ZAKLJUČCI DISCUSSION AND CONCLUSION}

Tehnološki napredak i specijalizacija radnika, kroz razne načine obuke i stručnog osposobljavanja u djelokrugu šumarstva, ima nemjerljivu korist za radnika i poslodavca s tehničkog, sigurnosnog i strukovnog gledišta, a s druge strane za pružatelja osposobljavanja postoje određena ograničenja. 
Bernasconio i Schroffa (2011) u okviru provedenog istraživanja profesija i programa osposobljavanja u šumarstvu kao prvo ograničenje ističu njihovu troškovnu zahtjevnost, pri čemu se to odnosi na brojnost praktičnih sati terenskog rada, poligonsku infrastrukturu i specijalizirana radna sredstva. S druge strane tržište za programe osposobljavanja je malo - mali je broj polaznika u odnosu na druge tečajeve. Drugo ograničenje vezano je za osiguranje dovoljnog broja odgovarajućih polaznika osposobljavanja na strukovnoj razini, npr. rukovatelja šumskih strojeva. Dodatno, izazov je zadržati obučene rukovatelje šumske mehanizacije u domicilnom sektoru, budući oni dobivaju široko znanje za rad i s drugim teškim strojevima (npr. građevinskim) te postaju tržišno zanimljivi sektorima gdje mogu više zaraditi. Kao treće ograničenje navodi se manjak interesa mladih generacija za tzv. 3D »black collar« poslove, pod čime se podrazumijeva fizički zahtjevan, opasan i prljav posao (engl. Dirty, Dangerous and Demeaning - 3D) - $\mathrm{u}$ takve poslove svrstava se i npr. radno mjesto šumskog radnika sjekača. Shodno navedenom, pretpostavka je da će se potencijal na tržištu rada znatno smanjiti u budućnosti tj. očekuje se manjak radne snage proizvodnih radnika u sektoru šumarstva.

S obzirom na brojne izazove s kojima se suočava šumarski sektor EU kao područje uske specijalizirane niše, međunarodna suradnja i formiranje klastera preuzima sve veće značenje, pri čemu vrlo važan postaje transfer znanja vezano za uspostavu saveza u načinu osposobljavanja, kao što je to u razvoju europskog standarda za rukovatelja motornom pilom. U zapadnim zemljama EU već desetljećima postoje specijalizirane ustanove kao šumarski trening centri koji pružaju sveobuhvatno osposobljavanje radnika iz tehničkog, sigurnosnog i strukovnog aspekta. Provodi se kroz ideju »dvojnog obrazovanja«, pri čemu se misli na prožimanje teorijskog učenja i praktičnog osposobljavanja (tj. treninga) unutar razdoblja obrazovanja. Takvim pristupom želi se dosegnuti visoki stupanj znanja i vještina. Stručno osposobljavanje, uporaba osobne zaštitne opreme i postupanje u skladu sa sigurnosnom radnom procedurom može znatno olakšati promociju sigurnosti i zdravlja tijekom izvođenja radnih procesa u šumi (Tsioras 2012). Važan element od vitalnog značaja za radnike u postupku osposobljavanja, kao preventivna mjere, je percepcija rizika unutar radnog okruženja koja treba biti temelj plana i programa osposobljavanja. Prema Medvedu (1998) te Martiniću i dr. (2011) obučavanje i periodično provjeravanje osposobljenosti rukovatelja šumarskom mehanizacijom u zemljama zapadne Europe već se desetljećima drže ključem kvalitete rada i sigurnosti operativnoga šumskoga rada. Obukom stečena znanja i vještine potvrđuju se obveznom provjerom i izdavanjem certifikata (npr. europskog certifikata za motornu pilu) kao dokaza o posjedovanju određenih profesionalnih znanja i vještina za siguran šumski rad, što rezultira višestrukom koristi i za radnika i za poslodavca (Martinić i dr. 2011).
Postupak osposobljavanja radnika za rad na siguran način te stručno osposobljavanje radnika za rad s radnim sredstvom u sektoru šumarstva Republike Hrvatske samo je u manjoj mjeri zadovoljavajuće uređeno. Osposobljavanje se provodi po programima koji nisu u potpunosti verificirani niti nezavisno ocijenjeni, a izostaje i nadzor nad ispunjavanjem kadrovskih i tehničkih resursa nositelja osposobljavanja. Zakonski propisi s općenito obvezujućim stavkama i utvrđeno stanje pokazuju da se osposobljavanje profesionalnih šumskih radnika sjekača ne provodi prema jedinstvenom nacionalnom kurikulumu, niti od strane adekvatno verificiranih nositelja osposobljavanja koji u potpunosti ne zadovoljavaju teoretskim i praktičnim elementima programa osposobljavanja te ne raspolažu svom potrebnom opremom, osobljem i infrastrukturom (Landekić i dr. 2016). Prvi pokušaj uvođenja reda i prevladavanja slabosti domaćeg sustava osposobljavanja predstavlja razvoj i implementacija strukovnog kurikuluma te standarda zanimanja i kvalifikacije »šumar « - višenamjenskog šumskog radnika koji je ekvivalent današnjeg šumskog radnika na radovima pridobivanja, uzgajanja, zaštite i dr. Navedeni pokušaj uvođenja reda svojedobno nije prepoznat te nije dobio očekivani "vjetar u leđa«struke, ponajprije zbog potrebitih opsežnih izmjena u legislativnim, strukturno-organizacijskim i obrazovnim dijelovima sustava.

Najizgledniji način povećanja sigurnosti u šumarstvu RH, za profesionalne radnike i amatere, je primjena i provedba dostignuća zemalja razvijenog šumarstva, što u sferi sigurnosti pri šumskom radu se posebno odnosi na provedbu certifikacije svih aspekata osposobljavanja za šumski rad. Uvažavajući sve navedeno, povezivanje $\mathrm{RH}$ u europske procese i programe vezane za sigurnost u šumarstvu moguće je implementacijom međunarodnih primjera dobre prakse kroz:

a) jaku promociju sustava sigurnosti i osvještavanje svih zainteresiranih u poduzetničkom lancu izvođenja šumskih radova (licencirani izvoditelji šumskih radova, obrazovne i zdravstvene institucije, proizvođači opreme, strukovna društva, strukovne udruge i dr.);

b) suradnju ključnih partnerskih organizacija hrvatskog šumarskog sektora u odabiru najmjerodavnije organizacije/ institucije za stjecanjem ovlasti nacionalne akreditacijske agencije za provedbu ECC (European Chainsaw Certifcate) programa, što podrazumijeva:

- formiranje radne skupine za pristupanje u EFESC uz logističku podršku operativnog tima stručnjaka $s$ pravnim i tehničkim znanjima;

- slanje pisma namjere tajništvu EFESC-a za pridruživanje te za stjecanje ovlasti nacionalne akreditacijske agencije; o čitavom postupku potrebno je izvijestiti Hrvatsku akreditacijsku agenciju (HAA), a po potrebi u konzultacijski tim uključiti predstavnika iz HAA-e;

- razvoj mreže suradničkih organizacija koje su nužne za ispunjavanje uvjeta/kriterija pristupanja u EFESC, 
što se prije svega odnosi na: srednje šumarske škole, proizvođače alata, strojeva i opreme, inspekciju rada, individualne konzultante i dr.

c) izmjene, dopune i/ili pripremu novih propisa (zakoni, uredbe, pravilnici) kako bi se osiguralo uvažavanje standardizacije osposobljavanja za šumski rad, uključujući ustrojavanje i funkcioniranja nacionalne akreditacijske agencije:

- izmjenama Pravilnika o zaštiti na radu u šumarstvu (N.N. 10/86) omogućiti ustrojavanje i djelovanje nacionalne agencije te šumarskog centra za obuku i ocjenjivanje, te istim uvesti obvezu certificiranja osposobljavanja za sve nositelje takvih aktivnosti u šumarstvu; - u okviru Zakona o šumama (N.N. 94/14) u poglavlju »Izvođenje šumarskih radova" i u okviru Zakona o zaštiti na radu (N.N. 71/14) u poglavlju ॥ Osposobljavanje za rad na siguran način « treba kao ključan uvjet dodati da izravni izvoditelji šumskih radova trebaju biti osposobljeni za rad na siguran način i za rad s radnim sredstvom kroz standardizirane sustave osposobljavanja koji su certificirani od nacionalne akreditacijske agencije;

- izradom središnjeg novooformljenog propisa, radnog naziva Pravilnik o certifikaciji osposobljavanja za šumski rad, detaljno urediti načine i kriterije certifikacije u svim elementima: treneri, verifikatori, pristupnici, nastavni kurikulumi, materijalno-tehnički (kabineti, poligoni) uvjeti i sl.;

d) verifikaciju od strane nacionalne akreditacijske agencije dva regionalna šumarska centra za obuku i ocjenjivanje (jedan za istočni i središnji dio, a drugi za gorski i mediteranski dio Hrvatske) s adekvatnom infrastrukturom za teoretski i praktični dio osposobljavanja, verificirane programe, predavače, instruktore, ocjenjivače i dr.:

- od strane Ministarstva znanosti i obrazovanja ishoditi ovlaštenje za izvođenje programa osposobljavanja uz prethodnu suglasnost Agencije za strukovno obrazovanje i obrazovanje odraslih.

Zaključno, navedene mjere unapređenja stanja sigurnosti i zaštite na radu od točke (a) do točke (d) potrebno je detaljno razraditi i implementirati kroz legislativni, strukturno-organizacijski i obrazovni koncept pomoću multidisciplinarnog istraživačkog tima u okviru nacionalnog projekta značajnog za sektor šumarstva.

\section{ZAHVALA}

\section{ACKNOWLEDGEMENTS}

Autori zahvaljuju CERCA programu Generalitata de Catalunya za podršku u izradi rada te nacionalnim agencijama EFESC-a na ustupljenim podacima vezanim za implementaciju europskog standarda za rukovatelja motornom pilom.

\section{LITERATURA}

\section{REFERENCES}

- Axelsson, S.Å., 1998: The mechanization of logging operations in Sweden and its effect on occupational safety and health. Int. J. Forest Eng., vol. 9, pp. 25-31.

- BBT, 2009: Glossar der geläufigen Terminologie im Kopenhagen-Prozess. $3 \mathrm{~S}$.

- Bell, J.L., 2002: Changes in logging injury rates associated with use of feller-bunchers in West Virginia. J Saf Res, vol. 33, pp.463471.

- Bentley, T., R. Parker, L. Ashby, 2005: Understanding felling safety in the New Zealand forest industry. Appl. Ergonomics, vol. 36, pp. 165-175.

- Bernasconi, A., U. Schroff, 2011: Professions and Training in Forestry. Results of an Inquiry in Europe and northern America. Federal Office for the Environment, Bern. 84 pp.

- Cabeças, J.M., 2007: An approach to health and safety in E.U. forestry operations - Hazards and preventive measures. Enterprise and Work Innovation Studies 3: 19-31.

- Driscoll, T., G. Ansari, J. Harrison, M. Frommer, E. Ruck, 1995: Traumatic work reated fatalities in forestry and sawmill in workers in Australia. J Safety Res, 26(4): 221-233.

- EFESC Handbook, 2015: Revised November 2015. Dostupno na http://efesc.org/data/images/frontend/documents/12_ EFESC\%20Handbook\%20\%20revised\%20Nov\%202015.pdf; [Accessed 06.07.2016.]

- Efthymiou, P.N., 2008: Wood Harvesting. Aristotle University of Thessaloniki, Thessaloniki.

- Garland, J.J., 1990: Assessing gains from woodsworker training. Int. J. Ind. Ergonomics, vol. 5, pp. 227-242.

- Godišnje poslovno izvješće HŠ, 2015. «ttp://portal.hrsume.hr/ images/stories/godisnja-poslovna-izvjesca/godisnje_izvjesce_ za_2015.pdf; [Accessed 20.12.2016.]

- Häggström, C., M. Öhman, L. Burström, T. Nordfjell, O. Lindroos, 2016: Vibration Exposure in Forwarder Work: Effects of Work Element and Grapple Type. Croat. J. of Forest Eng., vol. 37 (1), pp. 107-118.

- International Labour Organisation (ILO), 1981: Occupational Safety and Health problems in the Timber Industry. Geneva, Switzerland.

- International Labour Organization (ILO), 1991: Occupational Safety and Health in Forestry. Report II, Forestry and Wood Industries Committee, Second Session. Geneva: ILO.

- Klun, J., M. Medved, 2007: Fatal accidents in forestry in some European countries. Croat J For Eng, vol. 28 (1): 55-62.

- Landekić, M., 2010: Organizacija kultura i sigurnost pri radu u hrvatskom šumarskom sektoru. Šumarski list, 134 (11-12), str. 613-622.

- Landekić, M., I. Martinić, M. Šporčić, M. Bakarić, 2016: Tehnike rada i mjere sigurnosti pri radu na stablima u urbanim sredinama. VI. međunarodni stručno-znanstveni skup ZAŠTITA NA RADU I ZAŠTITA ZDRAVLJA. 21.-24. rujan 2016. godine, Zadar, Hrvatska, str. 362-374

- Lefort, A.J., C.P. de Hoop, J.C. Pine, 2003: Characteristics of injuries in the logging industry of Louisiana, USA: 1986 to 1998. Int J For Eng, vol 14, pp. 75-89.

- Lindroos, O., L. Burström, 2010: Accident rates and types among selfemployed private forest owners. Acc. Anal. Prev., vol 42, pp. 1729-1735. 
- Marenče, J., J. Krč, 2016: Possibilities of Using Small Tractors for Forestry Operations on Private Property. Croat. J. of Forest Eng., vol. 37 (1), pp. 151-162.

- Martinić, I., M. Landekić, M. Šporčić, M. Lovrić, 2011: Hrvatsko šumarstvo na pragu EU - koliko smo spremni na području sigurnosti pri šumskom radu?. Croat. J. of Forest Eng., vol. 32, str. 431-441.

- Martinić, I., M. Landekić, 2012: „Ocjena mogućnosti i uvjeta uključivanja u europsku mrežu za certificiranja šumskoga rada”. Elaborat - Definiranje modela za provedbu certificiranja u RH uključujući legislativni, tehničko-organizacijski i financijski okvir provedbe, str. 1-45.

- Medved, M., 1998: Nezgode in tveganje pri poklicnem in nepoklicnem delu v gozdu. GozdV 56(9): 379-389.

- MZOŠ (Ministarstvo znanosti, obrazovanja i sporta), 2011: Standard zanimanja šumar. 1-18 str. Dostupno na $\lfloor$ http://www. asoo.hr/UserDocsImages/Kurikulumi/SZ_Sumar_za\%20odobrenje_2013_02.pdf> [Accessed 05.09.2016.]

- MZOŠ projekt, 2013: Strategija za smanjenje nesreća i povećanje sigurnosti pri šumskom radu. Završno izvješće projekta MZOŠ 2008. - 2013. (voditelj i glavni istraživač prof. dr. sc. Ivan Martinić).

- Potočnik, I., T. Pentek, A. Poje, 2009: Severity Analysis of Accidents in Forest Operations, Croat. J. of Forest Eng., vol. 30, pp. 171-184.

- Smith, L.A., R.E. Thomas, 1993: Ergonomics research in the Southern United States. Unasylva (FAO), vol. 44 (no. 172), pp. 38-44.

- Sozialversicherung der Bauern, 1990: Extracts from official Austrian statistics submitted to the ILO (unpublished).
- Stadlmann, H., 1997: The accident situation in Austrian Forestry, with particular reference to Farm Forests. In the proceedings of the seminar „Safety and Health in Forestry are feasible!”, held in Konolfingen, 6-11 Oct. 1996, pp.127-131. BUWAL, Berne.

- Tsioras, P.A., P.N. Efthymiou, 2007: Need for forest workers' training in Greek forestry. Geotechnical Scientific Issues, vol 18, pp. 46-56. (In Greek with summary in English)

- Tsioras, P.A., 2010: Perspectives of the forest workers in Greece. iforest, vol. 3, pp. 118-123.

- Tsioras, P.A., 2012: Promotion of Safety in Forest Operations. International Virtual Conference on Advanced Research in Scientific Areas. December, 3.-7.2012, Slovakia, pp. 1395-1399. Dostupno na 〈http://www.arsa-conf.com〉 (Accessed 20.09.2016.)

- Wettman, O., 1992: Securité au travail dans l'exploitation forestière en Suisse. In FAO/ECE/ILO Proceedings of Seminar on the Future of the Forestry Workforce, edited by FAO/ECE/ ILO. Corvallis, OR: Oregon State University Press.

- Eduforest web-stranica, 2016. Dostupno na 〈http://www2.eduforest.eu/?lang = fr\&titre=formation-france-et europe\&rub=1\&srub=1\&body $=1$ > [Accessed 22.09.2016.]

- Europeanchainsaw web-stranica, 2016. Dostupno na http:// www.europeanchainsaw.eu/>_[Accessed 04.10.2016.]

- Visoka škola za sigurnost web-stranica, 2016. Dostupno na 〈http://obrazovanje.vss.hr/〉_[Accessed 13.09.2016.]

- Pravilnika o standardima i normativima te načinu i postupku utvrđivanja ispunjenosti uvjeta u ustanovama za obrazovanje odraslih (N.N. 129/08)

- Pravilnik o zaštiti na radu u šumarstvu (NN 10/86)

- Zakona o šumama (N.N. 94/14)

- Zakona o zaštiti na radu (N.N. 71/14)

\section{Summary}

The Introduction provides an overview of research findings related to danger and risk in the forestry profession toward other sectors through the standard indicators of safety at work on the example of the United States, Spain, Germany, Austria and other countries. On the other hand, training and periodical qualification verifying of the employee to work with the operating machinery and safe working practice are emphasized as an essential element in the process of improving the quality of work and safety in operational forestry. In addition, trends and changes in the education and training of human resources in forestry in general and the role of vocational training of forest workers in the prevention of injury and increase operational safety levels at work are cited.

The subtitle material and method provides the most relevant sources that are used as the basis for drafting paper, such as, a document entitled »Professions and Training in Forestry - results of an inquiry in Europe and North America«, Eduforest International internet platform and internet platform of the European Forestry and Environmental Skills Council. Also, for the purpose of the paper forming the application of analysis and synthesis, comparison and compilation methods is explained.

The third subtitle displays situation analysis of workers vocational training in forestry sector within which the Copenhagen Declaration is highlighted, which advocates strengthening and popularization of vocational education and training.

Networks and programs in the field of forestry training within Europe are listed in the Table 1., and more detailed analysis of registered educational institutions in the Eduforest network basis and the results of the analysis are shown in Figure 1 and Figure 2. Heading 3.1 clarifies the role of vocational training of workers in forestry. In addition, a positive step of vocational training of workers in forestry at European level is highlighted through the establishment of the European Forestry and Environmental Skills Council whose mission is to simplify the mobility of workers in forestry and arboriculture within the EU through processes of accreditation and promotion of individual national qualifications between the partner countries at European level. Current condition on vocational training for chainsaw operator in the forestry of Croatia are explained in 
subtitle 3.2. Inconsistent and incomplete programs and training activities, a significant reduction, or the absence of practical training and the use of non-transparent criteria in the carried out training assessment are cited as the biggest problem. Subtitle 3.3 clarifies the role and contribution of the European Forestry and Environmental Skills Council in the training of workers. The subtitle lists the criteria for acquiring the status of a national center / agency prescribed by EFESC Handbook, and the list of national agencies accredited by the EFESC in Table 2. The logo of the European Forestry and Environmental Skills Council is presented in Figure 4. Implementation of the European Chainsaw Standard is explained in the text and four levels of European Chainsaw Standards are presented in Figure 6. Figure 7 displays German example of the European Chainsaw Standards implementation, and Table 3 shows the implementation of European Chainsaw Certificate within EFESC countries.

The heading Discussion and Conclusion specify the limits of training and vocational training in the scope of forestry on the example of the dual education within the specialized institutions, namely, forestry training centers that provide comprehensive training in technical, safety and vocational aspect. In conclusion, in this paper the technical, organizational and legislative guidelines are listed for the potential implementation of the European model of certification of forest workers in the Croatian forestry with the aim of improving the current situation.

KEY WORDS: forestry, forest worker, vocational training, training, certification 